\title{
Histone acetylation in heterochromatin assembly
}

\author{
Jeong-Hoon Kim and Jerry L. Workman ${ }^{1}$ \\ Stowers Institute for Medical Research, Kansas City, Missouri 64110, USA
}

Histone acetylation is generally considered a mark involved in activating gene expression by making chromatin structures less compact. In the April 1, 2010, issue of Genes \& Development, Xhemalce and Kouzarides (pp. 647-652) demonstrate that the acetylation of histone $\mathrm{H} 3$ at Lys $4(\mathrm{H} 3 \mathrm{~K} 4)$ plays a role in the formation of repressive heterochromatin in Schizosaccharomyces pombe. H3K4 acetylation mediates a switch of chromodomain proteins associated with methylated H3K9 during heterochromatin assembly.

\section{Heterochromatin assembly in Schizosaccharomyces pombe}

Heterochromatin is characterized as being transcriptionally inactive and a highly condensed chromatin structure (Grewal and Moazed 2003; Grewal and Elgin 2007; Grewal and Jia 2007; Cam et al. 2009). Histone modifications generally associated with heterochromatin include hypoacetylation of lysines and di- or trimethylation of histone $\mathrm{H} 3$ at Lys 9 (H3K9me2 and H3K9me3) (James et al. 1989; Jenuwein. 2001; Peters et al. 2003; Rice et al. 2003). Heterochromatin protein 1 (HP1) specifically recognizes methylated H3K9 via its chromodomain, and is enriched in heterochromatic regions (Bannister et al. 2001; Lachner et al. 2001; Nakayama et al. 2001). This interaction represents an absolute requirement for heterochromatin formation in many organisms.

The fission yeast $S$. pombe has been used widely as a model organism for the study of heterochromatin assembly, as many factors involved in the formation of heterochromatin are conserved with the metazoa. In $S$. pombe, the centromere consists of a central region (cnt1) that functions as the site of kinetochore formation, and the pericentromeric outer region (otr) containing $d g$ and $d h$ repeats that are packaged into heterochromatin (Clarke and Baum 1990). Heterochromatin formation requires the coordinated actions of histone-modifying en-

[Keywords: H3K4ac; HP1; RITS complex; chromodomain switch; heterochromatin]

${ }^{1}$ Corresponding author.

E-MAIL jlw@stowers-institute.org; FAX (816) 926-4692.

Article is online at http://www.genesdev.org/cgi/doi/10.1101/gad.1922110. zymes Clr4 and Clr3 and HP1 proteins (Chp1, Chp2, and Swi6), as well as the RNAi machinery (Ekwall et al. 1996; Ivanova et al. 1998; Volpe et al. 2002; Motamedi et al. 2004; Verdel et al. 2004; Sugiyama et al. 2005). During $S$ phase of the cell cycle, limited exposure of sequences in heterochromatin allows for the transcription of the centromeric repeats by RNA polymerase II (RNA pol II). This in turn facilitates the recruitment of RNA-induced transcriptional gene silencing complex (RITS), which contains the Chp1 and Clr4 proteins (Verdel et al. 2004; Grewal and Elgin 2007; Chen et al. 2008; Cam et al. 2009). The transcribed centromeric repeat RNA is processed into siRNA by RITS and the RNA-dependent RNA polymerase complex (RDRC), which contains RNA-dependent RNA polymerase (Rdp1) and dicer (Dcr1) (Sugiyama et al. 2005). Methylation of Lys 9 on histone H3 by Clr4 recruits Swi6 and Chp2, and establishes a positive feedback loop by stabilizing the chromatin association of Clr4 and RITS through their chromodomains (Grewal and Jia 2007; Cam et al. 2009). During G2 phase, Chp2 recruits the Snf2/Hdac-containing complex (SHREC), which also includes the Clr3 histone deacetylase. Clr3 maintains the hypoacetylated state associated with heterochromatin (Sugiyama et al. 2007; Motamedi et al. 2008; Fischer et al. 2009).

Although several H3K9me-binding proteins required for heterochromatin formation have been identified, the mechanisms for their specific spatial and temporal recruitment have not been determined as yet.

The role of $\mathrm{H} 3 \mathrm{~K} 4$ acetylation in heterochromatin formation

Xhemalce and Kouzarides (2010) initially found that a histone H3K4R (Lys $\rightarrow$ Arg) mutation exhibited pericentromeric silencing defects. A set1 $\Delta$ mutant deficient in H3K4 methylation did not, suggesting that modification of Lys 4 other than methylation was involved in pericentromeric silencing. Acetylation of histone H3K4 (H3K4ac) has been described previously in both humans and mice (Garcia et al. 2007). Xhemalce and Kouzarides (2010) found that H3K4ac was indeed enriched at $d g$ and $d h$ heterochromatic repeats. Chromatin immunoprecipitation (ChIP) assays of pericentromeric heterochromatin revealed that levels of $\mathrm{H} 3 \mathrm{~K} 4 \mathrm{ac}$ peaked right after H3K9me2 during the cell cycle, suggesting sequential 
A

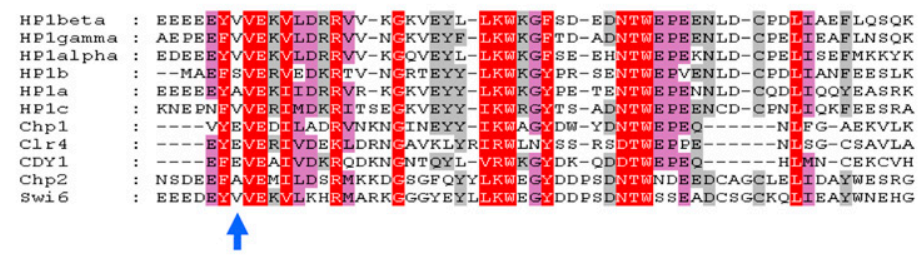

B
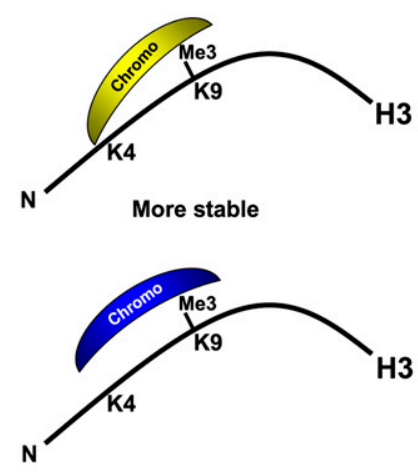
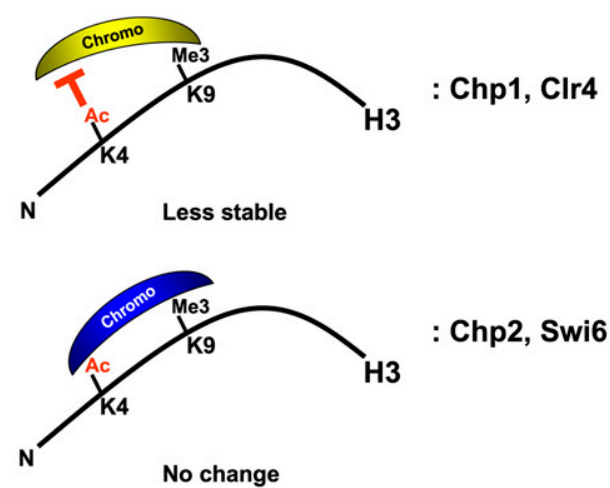

Figure 1. Sequence alignment of the chromodomains and model. (A) Amino acid sequences of the chromodomains of H3K9mebinding proteins (human HP1 $\alpha, \mathrm{HP} 1 \beta, \mathrm{HP} 1 \gamma$, and CDY1; Drosophila HP1a, HP1b, and HP1c; and $S$. pombe Swi6, Chp1, Chp2, and Clr4) were aligned using CLUSTALW and were presented by PSC geneDoc. The blue arrow indicates the location of the Glu residue contacting histone $\mathrm{H} 3$ Lys 4 . (B) A schematic diagram illustrating the model suggested in Xhemalce and Kouzarides (2010). The acetylation of $\mathrm{H} 3$ at Lys 4 destabilizes the interaction between $\mathrm{H} 3 \mathrm{~K} 9 \mathrm{me}$ and the chromodomain of Chp1 or Clr4. However, this model does not apply to the interaction of H3K9me with Chp2 or Swi6. actions of these two histone modifications. Furthermore, the H3K4R mutation caused increased occupancy of Chp1 and reduced association of Swi6 and Chp2 at both $d g$ and $d h$ repeats. This indicates that $\mathrm{H} 3 \mathrm{~K} 4 \mathrm{ac}$ mediates a switch between these chromodomain proteins in the pericentromeric region in vivo. Consistent with this possibility, peptide competition experiments revealed that Chp1 bound less stably to dimethylated H3K9 peptides also acetylated on H3K4 than to peptides only dimethylated on H3K9 (Fig. 1). In contrast, the binding of Swi6 and Chp2 to dimethylated H3K9 peptides was not influenced by $\mathrm{H} 3 \mathrm{~K} 4 \mathrm{ac}$. A potential reason for this difference in affinity may be that the Glu23 residue of Chp1 is not conserved in the chromodomains of Chp2 and Swi6 (Fig. 1). In the crystal structure of Chp1 bound to the H3 tail, Glu23 is linked to $\mathrm{K} 4$ of histone $\mathrm{H} 3$ via van der Waals interactions and a salt bridge (Schalch et al. 2009). Swi6 and Chp2 possess valine and alanine in this location, respectively. Among the chromodomains of proteins from other species also known to interact with $\mathrm{H} 3 \mathrm{~K} 9 \mathrm{me}$, only the human CDY1 chromodomain has a glutamate residue at the equivalent sites of $S$. pombe, Clr4 and Chp1, suggesting that a similar chromodomain switch may occur in humans (Fig. 1; Kim et al. 2006). Furthermore, the Drosophila HP1b protein contains a serine residue at the same site, which could mimic glutamate when phosphorylated (Fig. 1).

\section{Future perspective}

It is no longer surprising that different histone modifications at the same site can play opposing roles. Acetylated $\mathrm{H} 3 \mathrm{~K} 9$ is enriched at the promoter region of active genes, whereas methylation on the same site is associated with the gene body in inactive genes. Conversely, H3K4me is generated by the passage of RNA pol II and is associated with euchromatin, whereas $\mathrm{H} 3 \mathrm{~K} 4 \mathrm{ac}$ resides in heterochromatin (Li et al. 2007). This leads to the idea that
H3K4me may affect the level of H3K4ac and vice versa. While the set $1 \Delta$ mutant did not show a defect in centromeric heterochromatin formation, the possibility that methylation of $\mathrm{K} 4$ affects acetylation in a different region other than the pericentromeric region cannot be excluded. Interestingly, a recent publication showed that Lid2, a homolog of Lsd1 in mammals, demethylates trimethylated $\mathrm{H} 3 \mathrm{~K} 4$ and regulates heterochromatin formation in $S$. pombe, indicating that the removal of $\mathrm{H} 3 \mathrm{~K} 4 \mathrm{me}$ is required in heterochromatin assembly (Li et al. 2008).

In addition, Xhemalce and Kouzarides (2010) demonstrated that Mst1, a homolog of the human Tip60 acetyltransferase, and Sir2 deacetylase are responsible for the acetylation and deacetylation of $\mathrm{H} 3 \mathrm{~K} 4$, respectively. This finding is supported by previous studies, where an mst1 temperature-sensitive mutant caused a growth defect when combined with clr3s, clr4s, or swi6s (Gómez et al. 2008). Also, it has been shown previously that Sir2 is required for the hypoacetylation and methylation of H3K9 and association of Swi6 with heterochromatic regions (Shankaranarayana et al. 2003). It would be intriguing to explore how Mst1 is targeted to the pericentromeric region during $S$ phase. Interestingly, a direct interaction between trimethylated H3K9 peptide and the chromodomain of human Tip60 has been reported, which raises the possibility that $\mathrm{H} 3 \mathrm{~K} 9$ me may recruit Mst1 (Sun et al. 2009).

\section{Acknowledgments}

We thank all members of the Workman laboratory, especially Michaela Smolle for critical reading of the manuscript. This work was supported by NIGMS and the Stowers Institute.

\section{References}

Bannister AJ, Zegerman P, Partridge JF, Miska EA, Thomas JO, Allshire RC, Kouzarides T. 2001. Selective recognition of methylated lysine 9 on histone H3 by the HP1 chromo domain. Nature 410: 120-124. 
Cam HP, Chen ES, Grewal SI. 2009. Transcriptional scaffolds for heterochromatin assembly. Cell 136: 610-614.

Chen ES, Zhang K, Nicolas E, Cam HP, Zofall M, Grewal SI. 2008. Cell cycle control of centromeric repeat transcription and heterochromatin assembly. Nature 451: 734-737.

Clarke L, Baum MP. 1990. Functional analysis of a centromere from fission yeast: A role for centromere-specific repeated DNA sequences. Mol Cell Biol 10: 1863-1872.

Ekwall K, Nimmo ER, Javerzat JP, Borgstrøm B, Egel R, Cranston G, Allshire R. 1996. Mutations in the fission yeast silencing factors $\mathrm{clr} 4^{+}$and rik $1^{+}$disrupt the localisation of the chromo domain protein Swi6p and impair centromere function. J Cell Sci 109: 2637-2648.

Fischer T, Cui B, Dhakshnamoorthy J, Zhou M, Rubin C, Zofall M, Veenstra TD, Grewal SI. 2009. Diverse roles of HP1 proteins in heterochromatin assembly and functions in fission yeast. Proc Natl Acad Sci 106: 8998-9003.

Garcia BA, Hake SB, Diaz RL, Kauer M, Morris SA, Recht J, Shabanowitz J, Mishra N, Strahl BD, Allis CD, et al. 2007. Organismal differences in post-translational modifications in histones H3 and H4. J Biol Chem 282: 7641-7655.

Gómez EB, Nugent RL, Laria S, Forsburg SL. 2008. Schizosaccharomyces pombe histone acetyltransferase Mst1 (KAT5) is an essential protein required for damage response and chromosome segregation. Genetics 179: 757-771.

Grewal SI, Elgin SC. 2007. Transcription and RNA interference in the formation of heterochromatin. Nature 447: 399_ 406.

Grewal SI, Jia S. 2007. Heterochromatin revisited. Nat Rev Genet 8: 35-46.

Grewal SI, Moazed D. 2003. Heterochromatin and epigenetic control of gene expression. Science 301: 798-802.

Ivanova AV, Bonaduce MJ, Ivanov SV, Klar AJ. 1998. The chromo and SET domains of the Clr4 protein are essential for silencing in fission yeast. Nat Genet 19: 192-195.

James TC, Eissenberg JC, Craig C, Dietrich V, Hobson A, Elgin SC. 1989. Distribution patterns of HP1, a heterochromatinassociated nonhistone chromosomal protein of Drosophila. Eur J Cell Biol 50: 170-180.

Jenuwein T. 2001. Re-SET-ting heterochromatin by histone methyltransferases. Trends Cell Biol 11: 266-273.

Kim J, Daniel J, Espejo A, Lake A, Krishna M, Xia L, Zhang Y, Bedford MT. 2006. Tudor, MBT and chromo domains gauge the degree of lysine methylation. EMBO Rep 7: 397-403.

Lachner M, O'Carroll D, Rea S, Mechtler K, Jenuwein T. 2001. Methylation of histone $\mathrm{H} 3$ lysine 9 creates a binding site for HP1 proteins. Nature 410: 116-120.

Li B, Carey M, Workman JL. 2007. The role of chromatin during transcription. Cell 128: 707-719.

Li F, Huarte M, Zaratiegui M, Vaughn MW, Shi Y, Martienssen $\mathrm{R}$, Cande WZ. 2008. Lid2 is required for coordinating H3K4 and H3K9 methylation of heterochromatin and euchromatin. Cell 135: 272-283.

Motamedi MR, Verdel A, Colmenares SU, Gerber SA, Gygi SP, Moazed D. 2004. Two RNAi complexes, RITS and RDRC, physically interact and localize to noncoding centromeric RNAs. Cell 119: 789-802.

Motamedi MR, Hong EJ, Li X, Gerber S, Denison C, Gygi S, Moazed D. 2008. HP1 proteins form distinct complexes and mediate heterochromatic gene silencing by nonoverlapping mechanisms. Mol Cell 32: 778-790.

Nakayama J, Rice JC, Strahl BD, Allis CD, Grewal SI. 2001. Role of histone $\mathrm{H} 3$ lysine 9 methylation in epigenetic control of heterochromatin assembly. Science 292: 110-113.

Peters AH, Kubicek S, Mechtler K, O'Sullivan RJ, Derijck AA, Perez-Burgos L, Kohlmaier A, Opravil S, Tachibana M,
Shinkai Y, et al. 2003. Partitioning and plasticity of repressive histone methylation states in mammalian chromatin. Mol Cell 12: 1577-1589.

Rice JC, Briggs SD, Ueberheide B, Barber CM, Shabanowitz J, Hunt DF, Shinkai Y, Allis CD. 2003. Histone methyltransferases direct different degrees of methylation to define distinct chromatin domains. Mol Cell 12: 1591-1598.

Schalch T, Job G, Noffsinger VI, Shanker S, Kuscu C, Joshua-Tor L, Partridge JF. 2009. High-affinity binding of Chp1 chromodomain to $\mathrm{K} 9$ methylated histone $\mathrm{H} 3$ is required to establish centromeric heterochromatin. Mol Cell 34: 36-46.

Shankaranarayana GD, Motamedi MR, Moazed D, Grewal SI. 2003. Sir2 regulates histone $\mathrm{H} 3$ lysine 9 methylation and heterochromatin assembly in fission yeast. Curr Biol 13: 1240-1246.

Sugiyama T, Cam H, Verdel A, Moazed D, Grewal SI. 2005. RNA-dependent RNA polymerase is an essential component of a self-enforcing loop coupling heterochromatin assembly to siRNA production. Proc Natl Acad Sci 102: 152-157.

Sugiyama T, Cam HP, Sugiyama R, Noma K, Zofall M, Kobayashi R, Grewal SI. 2007. SHREC, an effector complex for heterochromatic transcriptional silencing. Cell 128: 491-504.

Sun Y, Jiang X, Xu Y, Ayrapetov MK, Moreau LA, Whetstine JR, Price BD. 2009. Histone H3 methylation links DNA damage detection to activation of the tumour suppressor Tip60. Nat Cell Biol 11: 1376-1382.

Verdel A, Jia S, Gerber S, Sugiyama T, Gygi S, Grewal SI, Moazed D. 2004. RNAi-mediated targeting of heterochromatin by the RITS complex. Science 303: 672-676.

Volpe TA, Kidner C, Hall IM, Teng G, Grewal SI, Martienssen RA. 2002. Regulation of heterochromatic silencing and histone H3 lysine-9 methylation by RNAi. Science 297: $1833-1837$.

Xhemalce B, Kouzarides T. 2010. A chromodomain switch mediated by histone H3 Lys 4 acetylation regulates heterochromatin assembly. Genes \& Dev 24: 647-652. 


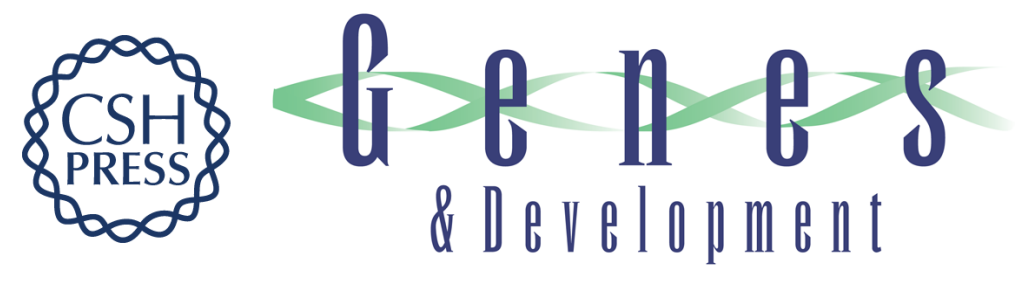

\section{Histone acetylation in heterochromatin assembly}

Jeong-Hoon Kim and Jerry L. Workman

Genes Dev. 2010, 24:

Access the most recent version at doi:10.1101/gad.1922110

Related Content A chromodomain switch mediated by histone H3 Lys 4 acetylation regulates heterochromatin assembly

Blerta Xhemalce and Tony Kouzarides

Genes Dev. April , 2010 24: 647-652

References This article cites 31 articles, 10 of which can be accessed free at:

http://genesdev.cshlp.org/content/24/8/738.full.html\#ref-list-1

Articles cited in:

http://genesdev.cshlp.org/content/24/8/738.full.html\#related-urls

\section{License}

Email Alerting Receive free email alerts when new articles cite this article - sign up in the box at the top Service right corner of the article or click here.

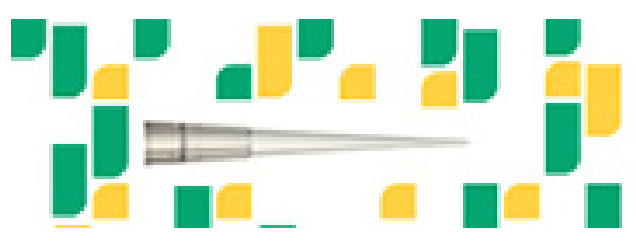

Focused on your science. 